\title{
Role of Meat in Healthy Eating Patterns: Considerations for Protein Quantity and Protein Quality
}

\author{
Nancy R. Rodriguez* \\ Department of Nutritional Sciences, University of Connecticut, Storrs, CT, 06269-4017, USA \\ *Corresponding author. Email: nancy.rodriguez@uconn.edu (Nancy R. Rodriguez)
}

\begin{abstract}
The benefits of higher-protein diets for supporting increases in and maintenance of muscle is well established for athletes and routinely active individuals, weight management, and aging. However, quantity does not always equal quality. Within the framework of the dietary recommendations, the critical role of protein quality has been lost given the complexity of our food system. Science shows that animal-derived proteins better support muscle protein synthesis than plant-based proteins due to higher amounts and unique profiles of essential amino acids, nutrients that cannot be made by the body and must be provided in the diet. Although the lower quality of plant-based proteins may be overcome by eating more total protein or blending complementary plant-based proteins to provide all of the essential amino acids in amounts similar to animal protein, there may be unintended consequences in the context of the total diet (e.g., higher total calories, challenges for weight management). This paper reviews recommendations and research specific to protein quantity and quality in the context of meat's contribution to healthy eating patterns and considers implications of protein source for sustainability and the environment.
\end{abstract}

Key words: meat, protein quantity, protein quality, protein source, healthy eating patterns

Meat and Muscle Biology 4(2): 18, 1-6 (2021) doi:10.22175/mmb.11687

Submitted 17 October $2020 \quad$ Accepted 11 December 2020

This paper was accepted as a contribution to the 2020 International Congress of Meat Science and Technology and the AMSA Reciprocal Meat Conference.

\section{Introduction}

The characteristics of an eating pattern that optimizes health outcomes while simultaneously being palatable, economically viable, sustainable, and environmentally friendly across the lifespan and various populations remain, for the most part, elusive. Embedded in this conundrum is the role of meat in healthy eating patterns given its widely valued role as a high-quality protein source and nutrient-dense food (Leroy and Cofnas, 2019; Willett et al., 2019; Drewnowski et al., 2020). This paper emphasizes protein recommendations for improved health and healthy aging, distinguishes protein quality from protein quantity, highlights the significance of essential amino acid (EAA) availability to muscle protein utilization, and extends the concept of EAA density to the role of meat in healthy eating patterns. Emerging perspectives for protein source, sustainability, and environmental impact are briefly considered in the context of this report.

\section{Protein Recommendations}

\section{Protein quantity}

Fundamental to life, protein provides structural components, EAA in particular, for numerous physiological functions and optimal health. Structurally similar to carbohydrate and fat in containing carbon, 
hydrogen, and oxygen, protein is unique in having nitrogen, an integral element of the amino group, as well as a respective Recommended Dietary Allowance (RDA). With specific regard for the latter, the requirement for dietary protein, or RDA (National Research Council Subcommittee on the Tenth Edition of the Recommended Dietary Allowances, 1989) is distinctly different from recommended protein intakes to optimize health (Wolfe and Miller, 2008; PaddonJones et al., 2015; Rodriguez and Miller, 2015).

Established in 1941, the RDA for protein $(0.8 \mathrm{~g} / \mathrm{kg}$ body weight) for adults was based on meeting EAA requirements and is an "estimate of the minimum daily average dietary intake level that meets the nutrient requirements of nearly all $(97 \%-98 \%)$ healthy individuals" (National Research Council Subcommittee on the Tenth Edition of the Recommended Dietary Allowances, 1989). Although the RDA for protein remains intact, recommendations for the macronutrient composition of the diet relative to total energy intake were launched in the inaugural publication of the Dietary Reference Intakes as the Acceptable Macronutrient Distribution Range (AMDR). The AMDR, expressed as a percentage of total calorie intake for protein $(10 \%-35 \%)$, carbohydrate $(45 \%-65 \%)$, and fat $(20 \%-35 \%)$, provides adequate amounts of essential nutrients and is associated with reduced risk for chronic disease (Institute of Medicine, 2005). Of significance to this paper is evidence documenting protein intake across the lifespan as adequate to meet the RDA, yet consistently below the upper range of the AMDR (Berryman et al., 2018). In addition, consuming protein at the low range of the AMDR (i.e., 10\%) may be inadequate and not meet the RDA for some populations (Wolfe and Miller, 2008). The AMDR provides flexibility in diet design and the opportunity to increase protein intake to amounts that exceed the RDA and are associated with improved health outcomes. Documentary evidence describes the benefits of consuming higher amounts of dietary protein to facilitate the prevention and management of chronic diseases such as obesity, the sarcopenia of aging, and various cardiometabolic disorders (i.e., type 2 diabetes, hypertension) (Gaffney-Stomberg et al., 2009; Devkota and Layman, 2010; Evans et al., 2012; Layman et al., 2015; Paddon-Jones et al., 2015; Rodriguez, 2015; Rodriguez and Miller, 2015). The challenge that currently exists is that higher protein intakes alone may not be of sufficient quality to meet requirements for EAA, nutrients that are indispensable to the diet because they cannot be made by the body.

\section{Protein quality}

When the RDA for protein was conceived, the subcommittee considered requirements for the EAA (National Research Council Subcommittee on the Tenth Edition of the Recommended Dietary Allowances, 1989), a fact that has been lost in translation over recent years. In contemporary nutrition, protein intake is typically characterized in the context of protein quantity without consistent or specific regard for the EAA that are the basis of protein quality. Complete proteins provide all 9 EAA-histidine, isoleucine, leucine, lysine, methionine phenylalanine, threonine, tryptophan, and valine. Yet not all complete proteins are of equal quality. High-quality proteins are complete proteins that provide sufficient amounts of all of the EAA to support growth, development, and maintenance of body tissues. While some plant proteins are complete (i.e., pea protein), their EAA profile is limiting, or low, in some EAA, making them insufficient for optimal growth and development.

Meeting EAA requirements in the context of healthy eating patterns is accomplished by incorporating complete, high-quality proteins such as lean meats, eggs, and dairy foods at each meal. However, many consumers have become reluctant to consume animal proteins owing to concerns for increased risk for cardiovascular and other chronic diseases (i.e., cancer), as well as for sustainability of the environment (Katz et al., 2019). Subsequently, plant-based protein sources have become more prevalent in eating patterns characterized as healthy and environmentally friendly (Gardner et al., 2019; Katz et al., 2019; Mariotti and Gardner, 2019; Willett et al., 2019). Whether routine consumption of primarily plant-based eating patterns is EAA sufficient for optimal protein utilization is not known.

The majority of work done to characterize the skeletal muscle protein synthetic response has been done with high-quality protein sources (van Vliet et al., 2015; Tessari et al., 2016; van Vliet et al., 2017). Indeed, Borsheim and colleagues (Borsheim et al., 2002, 2010) have demonstrated that only EAA are needed to achieve a positive net protein balance (i.e., protein synthesis $>$ protein breakdown), an anabolic scenario. In addition, the EAA leucine is well documented as a nutrient signal, or trigger, that stimulates muscle protein synthesis (Tessari et al., 2016). Our group has successfully implemented this approach to diet and exercise interventions to increase dietary leucine intake and support whole body and skeletal muscle protein synthesis (Bolster et al., 2005; Gaine et al., 
2006; Pikosky et al., 2006; Pasiakos et al., 2010). Meat -a complete, high-quality protein source that is EAA and micronutrient dense-was incorporated into healthy eating patterns for habitual consumption throughout the various dietary intervention periods in these studies.

Although available evidence demonstrates that animal-derived proteins better support muscle protein synthesis than plant-based proteins due to their higher EAA content, the lower quality of plant-based proteins may be overcome by consuming more total protein or blending complementary plant-based proteins to obtain sufficient amounts of EAA. However, simply increasing protein intake to achieve sufficient EAA to promote optimal muscle health may be accompanied by the unintended consequence of additional calories. This led us to consider EAA density represented by the amount of EAA relative to total calories or total protein as a novel approach for evaluating protein quality in healthy eating patterns (Rodriguez and Miller, 2015).

\section{EAA density}

Protein quality, a critical concept in considering nutrient density of foods, is not addressed in the United States Department of Agriculture (USDA) Dietary Guidelines for Americans (DGA). The DGA definition of nutrient-dense foods focuses on foods that "provide vitamins, minerals, and other substances that contribute to adequate nutrient intakes" (Institute of Medicine, 2005) without mention of EAA. This is a critical oversight when considering the ounce equivalents for the protein food group of the DGA.

USDA healthy eating patterns reference 1 ounce of meat, poultry, or seafood, $1 \mathrm{egg}, 1 / 4$ cup of beans or tofu,
1 tablespoon peanut butter, and $1 / 2$ ounce of nuts as 1-ounce protein equivalents. Dietary exchanges for protein equivalents should provide equal amounts of protein and calories. With specific regard for protein quality, consideration for EAA content is critical. In reality, the aforementioned ounce equivalents contain different amounts of protein, calories, and EAA. For example, in considering the EAA density of 1-ounce protein equivalents in meeting EAA requirements, 1 ounce of beef or 1 egg each provide $\sim 20 \%$ of the daily EAA requirement, whereas $1 / 4$ cup of cooked beans and 1 tablespoon of peanut butter provide approximately $1.4 \%$ and $0.5 \%$ of the EAA requirement, respectively. Therefore approximately 5 ounces of beef, 5 hardboiled eggs, 18 cups of beans (i.e., chickpeas), or 50 tablespoons of peanut butter would need to be consumed to meet the daily EAA requirement. The discrepancies in protein quantity and protein quality between plant and animal protein ounce equivalents is more significant when calories are considered. Therefore, an equal exchange of plant-based protein sources for animal sources is not possible without compromising EAA adequacy or the calorie content of heathy eating patterns, especially for older populations.

We considered the EAA content, adequacy, and density (the amount of EAA relative to total calories or total protein) of animal- and plant-based protein equivalents in the context of 4 USDA healthy eating patterns-Omnivore, Vegetarian, Vegan Energy Matched, and Vegan Protein Matched (Table 1) using the 1,600-calorie recommendation for a sedentary woman aged 51 years (Institute of Medicine, 2005) and found that the EAA content of all 4 meal patterns met established EAA RDA (Figure 1; Fussell et al., 2021). However, matching total protein to

Table 1. Energy and macronutrient content of omnivore, vegetarian, vegan energy matched, and vegan protein matched meal patterns

\begin{tabular}{lccrr}
\hline \hline & Omnivore & Vegetarian & Vegan Energy Matched & Vegan Protein Matched \\
\hline Energy (kcal) & 1,615 & 1,677 & 1,614 & 1,972 \\
Fat (g) & 58 & 57 & 58 & 68 \\
Fat (\% energy) & $32 \%$ & $31 \%$ & $33 \%$ & $31 \%$ \\
Carbohydrate (g) & 212 & 234 & 230 & 278 \\
Carbohydrate (\% energy) & $52 \%$ & $56 \%$ & $57 \%$ & $56 \%$ \\
Protein (g) & 75 & 73 & $14 \%$ & 73 \\
Protein (\% energy) & $18 \%$ & $18 \%$ & 1.0 & 1.3 \\
Protein (g/kg BW) & 1.3 & 1.3 & 0 & 0 \\
Animal Protein & 49 & 38 & 0 & 0 \\
Animal protein (\% protein) & $64 \%$ & $52 \%$ & 56 & 73 \\
Plant Protein & 20 & 35 & $100 \%$ & $100 \%$ \\
Plant protein (\% protein) & $26 \%$ & $48 \%$ & & 0 \\
\hline
\end{tabular}

$\mathrm{BW}=$ body weight. 


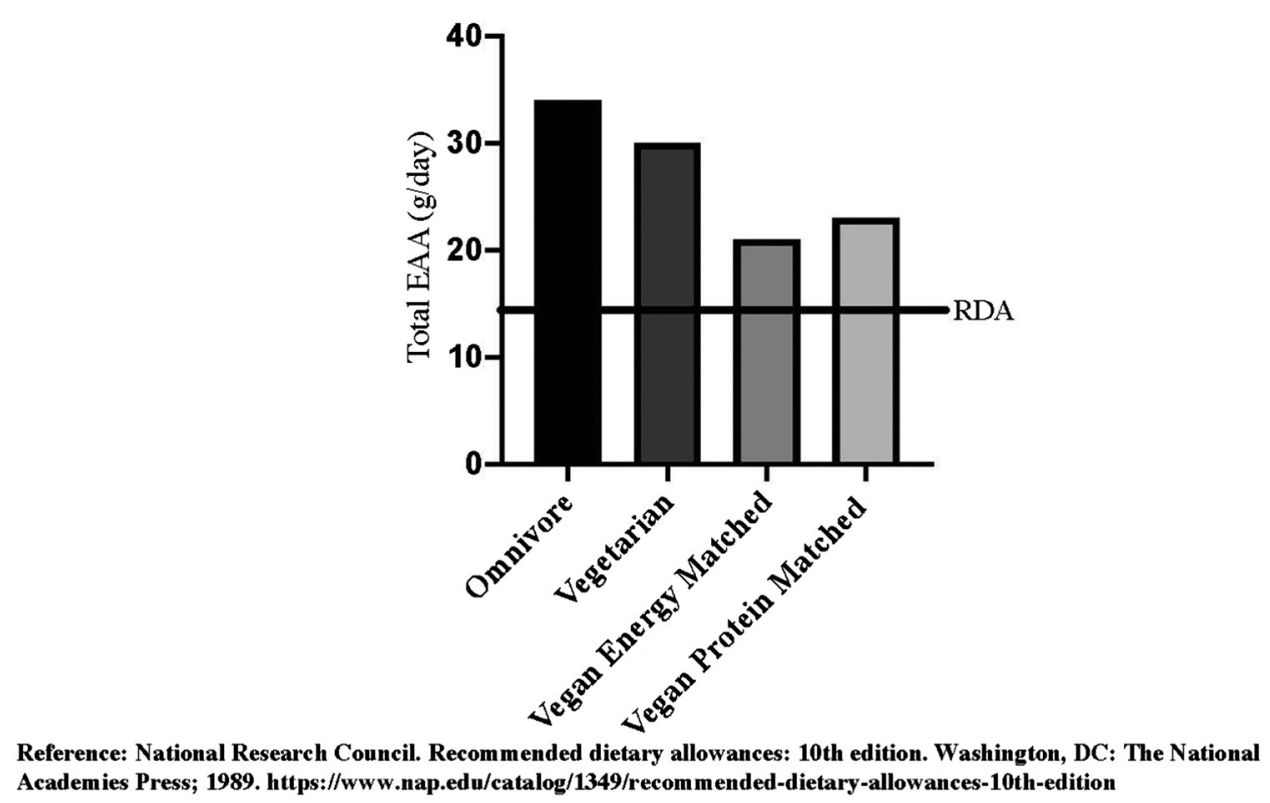

Figure 1. Total essential amino acid (EAA) content of omnivore, vegetarian, vegan energy matched, and vegan protein matched meal patterns compared with the Recommended Dietary Allowance (RDA).

accommodate recommended protein intakes for healthy aging resulted in an additional 300 calories for the Vegan Protein Matched meal pattern.

EAA density-calculated for total protein (Figure 2a) and for total calories (Figure 2b) for each meal pattern-decreased moving from Omnivore to Vegetarian to Vegan Energy Matched to Vegan Protein Matched meal patterns. The decline was more evident when EAA density was expressed relative to total calories (Fussell et al., 2021). Critically, the calorie cost of obtaining adequate protein and meeting EAA requirements from plant-based protein sources should not be overlooked when developing and implementing healthy eating patterns for older populations. This concern persists with plant-based meal patterns aimed to improve health while reducing environmental impact (Gardner et al., 2019). In proposing meal scenarios that depicted different options for the amount and source of dietary protein as beneficial to environmental outcomes, Gardner and colleagues were transparent with regard to the additional calories needed to accommodate plant-based protein equivalents. The increased calorie content of the alternative plates approximated 200 calories, which was not considered consequential by the researchers. However, if the recommended adjustments were made and the meal pattern became habitual, the routine consumption of an additional 200 calories/d could elicit a 10- to $15-1 b$ increase in body weight annually. This hypothetical estimate highlights the challenges to designing calorie-efficient healthy eating patterns for older men and women.

\section{Summary and Recommendation}

In recent years, there has been increased interest in and sensitivity to the intersection of diet, health, and sustainability (Gardner et al., 2019; Katz et al., 2019; Leroy and Cofnas, 2019; Willett et al., 2019). A thorough discussion of the role of protein sources in particular and recommended healthy eating patterns in general is outside of the purview of this paper. Whether food patterns consisting primarily of plantbased protein sources, or void of red meat in total, will improve environmental outcomes is a contemporary debate without resolution at this time (Godfray et al., 2018). Such a leap of faith without sufficient scientific evidence to support these dietary changes is ill advised. The concept of sustainable agriculture is complex and the impact of meat consumption on the environment oversimplified. Diet modeling that considers increased plant-based protein sources suggests concerns for micronutrient inadequacies (Cifelli et al., 2016; Houchins et al., 2017). The latter combined with unintentional increases in calorie intake would have health consequences. Therefore, caution is required when considering the removal of animal-derived proteins from the diet.

Whole foods consumed in healthy eating patterns -lean beef, dairy, and eggs_-are rich sources of leucine, have a more robust and consistent EAA profile, and are more anabolic than their plant-based counterparts (van Vliet et al., 2015). Maintenance of muscle health and appropriate body composition are 


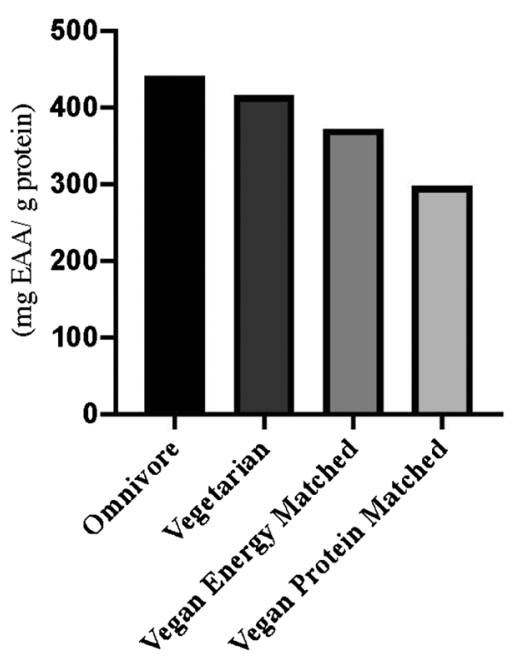

(a)

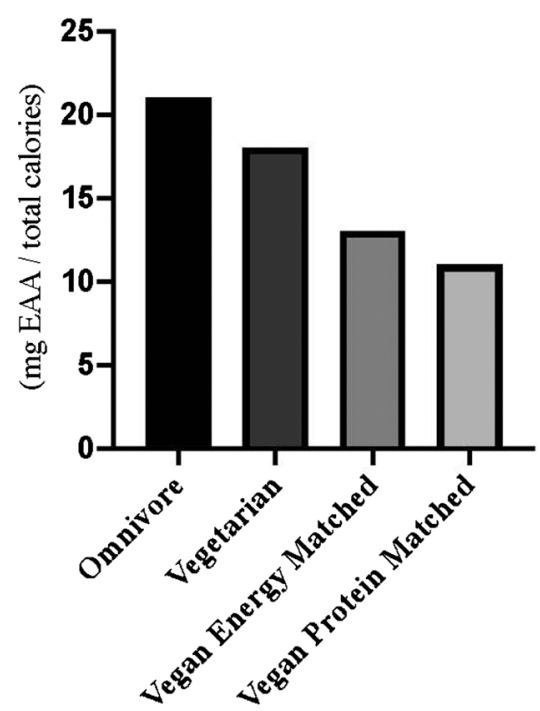

(b)

Figure 2. (a) Essential amino acid (EAA) density calculated for total protein. (b) Essential amino acid (EAA) density calculated for total calories.

the foundation of healthy aging. The fact that additional calories accompany higher-protein, EAA-adequate, plant-based meal patterns requires further deliberation with a regard for healthy aging. Most healthy men and women should consume protein intakes above the RDA for the prevention and management of chronic disease, as well as the maintenance of muscle as they grow older. Routine consumption of high-quality animal proteins assists in these directives, and as nutrientdense food sources, these proteins contribute to optimal nutritional status. High-quality protein sources are suitable for the design of healthy, nutrient-rich, and calorie-conscious eating patterns. In moving forward, caution is required in navigating the crossroads of health, nutrition, sustainability, and the environment given the limited scientific evidence to date.

\section{Acknowledgments}

This work was supported by the USDA National Institute of Food and Agriculture Hatch project (accession number 1016873) and was funded in part by the Beef Checkoff.

\section{Literature Cited}

Berryman, C. E., H. R. Lieberman, V. L. Fulgoni, and S. M. Pasiakos. 2018. Protein intake trends and conformity with the dietary reference intakes in the united states: Analysis of the national health and nutrition examination survey, 2001-2014. Am. J. Clin. Nutr. 108:405-413. https://doi. org/10.1093/ajcn/nqy088.

Bolster, D. R., M. A. Pikosky, P. C. Gaine, W. Martin, R. R. Wolfe, K. D. Tipton, D. Maclean, C. M. Maresh, and N. R. Rodriguez. 2005. Dietary protein intake impacts human skeletal muscle protein fractional synthetic rates after endurance exercise. Am. J. Physiol.-Endoc. M. 289:E678-E683. https://doi.org/10.1152/ajpendo.00060.2005.

Borsheim, E., D. L. Chinkes, S. J. McEntire, N. R. Rodriguez, D. N. Herndon, and O. E. Suman. 2010. Whole body protein kinetics measured with a non-invasive method in severely burned children. Journal of the International Society for Burn Injuries. 36:1006-1012. https://doi.org/10.1016/j. burns.2010.01.007.

Borsheim, E., Tipton, K. D., Wolf, S. E., and Wolfe, R. R. 2002. Essential amino acids and muscle protein recovery from resistance exercise. Am. J. Physiol.-Endoc. M. 283:E648-E657. https://doi.org/10.1152/ajpendo.00466.2001.

Cifelli, C. J., J. A. Houchins, E. Demmer, and V. L. Fulgoni. 2016. Increasing plant based foods or dairy foods differentially affects nutrient intakes: Dietary scenarios using NHANES 2007-2010. Nutrients. 8:422. https://doi.org/10. 3390/nu8070422.

Devkota, S., and D. K. Layman. 2010. Protein metabolic roles in treatment of obesity. Curr. Opin. Clin. Nutr. 13:403-407. https://doi.org/10.1097/MCO.0b013e32833a7737.

Drewnowski, A., J. Finley, J. M. Hess, J. Ingram, G. Miller, and C. Peters. 2020. Toward healthy diets from sustainable food systems. Current Developments in Nutrition. 4:nzaa083. https:// doi.org/10.1093/cdn/nzaa083.

Evans, E. M., M. C. Mojtahedi, M. P. Thorpe, R. J. Valentine, P. M. Kris-Etherton, and D. K. Layman. 2012. Effects of protein intake and gender on body composition changes: A randomized clinical weight loss trial. Nutr. Metab. 9:55. https://doi. org/10.1186/1743-7075-9-55.

Fussell, M., A. Contillo, H. Druehl, and N. R. Rodriguez. 2021. Essential amino acid density: Differences in animal- and plant-based dietary patterns. Nutr. Today. Published ahead of print. https://doi.org/10.1097/NT.0000000000000466.

Gaffney-Stomberg, E., K. L. Insogna, N. R. Rodriguez, and J. E. Kerstetter. 2009. Increasing dietary protein requirements in 
elderly people for optimal muscle and bone health. J. Am. Geriatr. Soc. 57:1073-1079. https://doi.org/10.1111/j.15325415.2009.02285.x

Gaine, P. C., M. A. Pikosky, W. F. Martin, D. R. Bolster, C. M. Maresh, and N. R. Rodriguez. 2006. Level of dietary protein impacts whole body protein turnover in trained males at rest. Metabolism. 55:501-507. https://doi.org/10.1016/j.metabol. 2005.10.012.

Gardner, C. D., J. C. Hartle, R. D. Garrett, L. C. Offringa, and A. S. Wasserman. 2019. Maximizing the intersection of human health and the health of the environment with regard to the amount and type of protein produced and consumed in the United States. Nutr. Rev. 77:197-215. https://doi.org/10. 1093/nutrit/nuy073.

Godfray, H. C. J., P. Aveyard, T. Garnett, J. W. Hall, T. J. Key, J. Lorimer, R. T. Pierrehumbert, P. Scarborough, M. Springmann, and S. A. Jebb. 2018. Meat consumption, health, and the environment. Science. 361:eaam5324. https://doi.org/ 10.1126/science.aam5324.

Houchins, J. A., C. J. Cifelli, E. Demmer, and V. L. Fulgoni. 2017. Diet modeling in older Americans: The impact of increasing plant-based foods or dairy products on protein intake. J. Nutr. Health Aging. 21:673-680. https://doi.org/10.1007/s12603016-0819-6.

Institute of Medicine. 2005. Dietary reference intakes for energy, carbohydrate, fiber, fat, fatty acids, cholesterol, protein, and amino acids. The National Academies Press, Washington, DC.

Katz, D. L., K. N. Doughty, K. Geagan, D. A. Jenkins, and C. D. Gardner. 2019. Perspective: The public health case for modernizing the definition of protein quality. Adv. Nutr. 10:755764. https://doi.org/10.1093/advances/nmz023.

Layman, D. K., T. G. Anthony, B. B. Rasmussen, S. H. Adams, C. J. Lynch, G. D. Brinkworth, and T. A. Davis. 2015. Defining meal requirements for protein to optimize metabolic roles of amino acids. Am. J. Clin. Nutr. 101:1330S-1338S. https://doi. org/10.3945/ajen.114.084053.

Leroy, F., and N. Cofnas. 2019. Should dietary guidelines recommend low red meat intake? Crit. Rev. Food Sci. 60:27632772. https://doi.org/10.1080/10408398.2019.1657063.

Mariotti, F., and C. D. Gardner. 2019. Dietary protein and amino acids in vegetarian diets-A review. Nutrients. 11:2661. https://doi.org/10.3390/nu11112661.

National Research Council (US) Subcommittee on the Tenth Edition of the Recommended Dietary Allowances. 1989. Recommended dietary allowances: 10th edition. https://doi. org/10.17226/1349.

Paddon-Jones, D., W. W. Campbell, P. F. Jacques, S. B. Kritchevsky, L. L. Moore, N. R. Rodriguez, L. J. van Loon. 2015. Protein and healthy aging. Am. J. Clin. Nutr. 101:1339S-1345S. https://doi.org/10.3945/ajen.114.084061.
Pasiakos, S. M., L. M. Vislocky, J. W. Carbone, N. Altieri, K. Konopelski, H. C. Freake, J. M. Anderson, A. A. Ferrando, R. R. Wolfe, and N. R. Rodriguez. 2010. Acute energy deprivation affects skeletal muscle protein synthesis and associated intracellular signaling proteins in physically active adults. J. Nutr. 140:745-751. https://doi.org/10.3945/jn.109. 118372 .

Pikosky, M. A., P. C. Gaine, W. F. Martin, K. C. Grabarz, A. A. Ferrando, R. R. Wolfe, and N. R. Rodriguez. 2006. Aerobic exercise training increases skeletal muscle protein turnover in healthy adults at rest. J. Nutr. 136:379-383. https://doi. org/10.1093/jn/136.2.379.

Rodriguez, N. R. 2015. Introduction to protein summit 2.0: Continued exploration of the impact of high-quality protein on optimal health. The American Journal of Clinical Nutrition. 101:1317S-1319S. https://doi.org/10.3945/ajcn. 114.083980 .

Rodriguez, N. R., and S. L. Miller. 2015. Effective translation of current dietary guidance: Understanding and communicating the concepts of minimal and optimal levels of dietary protein. Am. J. Clin. Nutr. 101:1353S-1358S. https://doi.org/10. 3945/ajcn.114.084095.

Tessari, P., A. Lante, and G. Mosca. 2016. Essential amino acids: Master regulators of nutrition and environmental footprint? Sci. Rep.-UK. 6:26074. https://doi.org/10.1038/srep26074.

van Vliet, S., N. A. Burd, and L. J. van Loon. 2015. The skeletal muscle anabolic response to plant- versus animal-based protein consumption. J. Nutr. 145:1981-1991. https://doi.org/10. 3945/jn.114.204305.

van Vliet, S., E. L. Shy, S. Abou Sawan, J. W. Beals, D. W. West, S. K. Skinner, A. V. Ulanov, Z. Li, S. A. Paluska, C. M. Parsons, D. R. Moore, and N. A. Burd. 2017. Consumption of whole eggs promotes greater stimulation of postexercise muscle protein synthesis than consumption of isonitrogenous amounts of egg whites in young men. Am. J. Clin. Nutr. 106:1401-1412. https://doi.org/10.3945/ajen.117.159855.

Willett, W., J. Rockstrom, B. Loken, M. Springmann, T. Lang, S. Vermeulen, T. Garnett, D. Tilman, F. DeClerck, A. Wood, M. Jonell, M. Clark, L. J. Gordon, J. Fanzo, C. Hawkes, R. Zurayk, J. A. Rivera, W. De Vries, L. M. Sibanda, A. Afshin, A. Chaudhary, M. Herrero, R. Agustina, F. Branca, A. Lartey, S. Fan, B. Crona, E. Fox, V. Bignet, M. Troell, T. Lindahl, S. Singh, S. E. Cornell, K. S. Reddy, S. Narain, S. Nishtar, and C. J. L. Murray. 2019. Food in the anthropocene: The EAT-Lancet Commission on healthy diets from sustainable food systems. Lancet. 393:447-492. https://doi.org/ S0140-6736(18)31788-4.

Wolfe, R. R., and S. L. Miller. 2008. The recommended dietary allowance of protein: A misunderstood concept. JAMA-J. Am. Med. Assoc. 299:2891-2893. https://doi.org/10.1001/ jama.299.24.2891. 